D) Check for updates

Cite this: Food Funct., 2021, 12, 6780

\title{
Antimicrobial activity, chemical composition and cytotoxicity of Lentinus crinitus basidiocarp
}

\author{
Míria Benetati Delgado Bertéli, (DD a Lillian Barros, (DD b ${ }^{\mathrm{b}}$ Filipa S. Reis, ${ }^{\mathrm{b}}$ \\ Isabel C. F. R. Ferreira, (DD ${ }^{b}$ Jasmina Glamočlija, (D) ${ }^{c}$ Marina Soković, (D) ${ }^{c}$ \\ Juliana Silveira do Valle, ${ }^{a}$ Giani Andrea Linde, (D) ${ }^{a}$ Suelen Pereira Ruiz ${ }^{a}$ and \\ Nelson Barros Colauto (D)*a
}

\begin{abstract}
Lentinus crinitus (L.) Fr. (Basidiomycota: Polyporales) is a wild mushroom with several biotechnological applications; however, there are few studies on its chemical composition and antimicrobial activity. Therefore, this study aims to evaluate the chemical composition, cytotoxicity, and antimicrobial activity of L. crinitus basidiocarp. For that, its nutritional value (AOAC procedures) and its composition in some hydrophilic and lipophilic compounds (chromatographic techniques) were assessed. Moreover, the potential hepatotoxic effects were evaluated using a primary cell culture obtained from porcine liver, and its growth inhibitory capacity was also evaluated against four human tumour cell lines (spectrophotometric assays). The antimicrobial activity was evaluated by microdilution against eight bacteria and fungi. The basidiocarp has a high content of carbohydrates and, therefore, a relatively high energetic value. It is also rich in soluble sugars, $\beta$-tocopherol, phenolic acids, mainly $p$-hydroxybenzoic acid, and organic acids, mainly malic acid. L. crinitus did not show cytotoxicity in non-tumour cells, but it did not inhibit the growth of human tumour cell lines either. The basidiocarp has a wide antimicrobial activity, inhibiting the growth of different species of bacteria and fungi. It showed minimum bactericidal and fungicidal concentration values similar to or lower than those verified by commercial antibiotics or food additives used as preservatives. The antimicrobial activity was more evident against Listeria monocytogenes, Salmonella enterica, and Penicillium ochrochloron, followed by Aspergillus ochraceus and Trichoderma viride, when compared to the controls. The results obtained in this study showed that $L$. crinitus basidiocarp has great potential to be used by the industry without toxicity risks.
\end{abstract}

Received 2nd March 2021 Accepted 6th May 2021

DOI: $10.1039 / \mathrm{d} 1 \mathrm{fo} 00656 \mathrm{~h}$

rsc.li/food-function a source of protein by indigenous people from Yanomami and Txicão tribes in Brazil, Uitoto, Muinane, and Andoke in Colombia, Hoti in Venezuela, and the rural population of Loreto in Peru. ${ }^{9}$ There are some reports on its antioxidant potential, ${ }^{10}$ metal bioaccumulation capacity, ${ }^{11,12}$ and high enzyme production capacity (i.e. laccase, ${ }^{13}$ protease, ${ }^{14}$ and xylanase $\left.\mathrm{e}^{15}\right)$. We can find some studies regarding the nutritional potential of this mushroom, namely its content in ashes, fat, protein, and total carbohydrates. ${ }^{16-18}$ To the best of our knowledge, the antimicrobial potential of $L$. crinitus basidiocarp has been reported just against Fusarium sp. conidium sporulation. ${ }^{19}$ However, there are no detailed reports on its chemical characterization, cytotoxicity, or antimicrobial activity against foodborne pathogens.

Foodborne diseases are one of the major burdens to public health, caused by the consumption of contaminated foods with pathogenic microorganisms or their toxins. ${ }^{20,21}$ The main contaminants of food are bacteria ${ }^{20}$ and mycotoxins, resulting in average costs of 100 billion dollars per year for developing countries. $^{22}$ Some of these pathogenic microorganisms

\footnotetext{
${ }^{a}$ Paranaense University, Molecular Biology Laboratory, 87502-210 Umuarama, PR, Brazil. E-mail: nelsonbcolauto@gmail.com; Tel: +55 (44)991391112

${ }^{b}$ Centro de Investigação de Montanha (CIMO), Instituto Politécnico de Bragança, Campus de Santa Apolónia, 5300-253 Bragança, Portugal

${ }^{c}$ Mycological Laboratory, Mycology, Department of Plant Physiology, Institute for Biological Research "Siniša Stanković" - National Institute of Republic of Serbia, University of Belgrade, Bulevar despota Stefana 142, 11000 Belgrade, Serbia
} 
include Pseudomonas aeruginosa, a multi-drug resistant bacterium, ${ }^{23}$ Listeria monocytogenes, which develops multidrug resistance, ${ }^{24}$ and Bacillus cereus which causes food intoxication. ${ }^{25}$ Therefore, these are relevant bacteria that cause foodborne diseases to be controlled with new compounds. Several synthetic chemical compounds, such as nitrates, benzoates, sulfites, and sorbates are applicable to foods for their preservation. However, some of these compounds have been related to undesirable effects on human health such as allergies or even carcinogenic effects. ${ }^{21,26,27}$ Thus, the search for natural compounds as an alternative for food preservation has been one of the fields of interest of scientific research in recent years. Thus, this study aimed to evaluate the chemical composition, cytotoxicity, and antimicrobial activity of L. crinitus basidiocarp grown on agro-industrial residues, contributing to the food science and technology field.

\section{Materials and methods}

\subsection{Biological material}

This study used Lentinus crinitus (L.) Fr. (Basidiomycota: Polyporales) U9-1 strain from the Culture Collection of the Laboratory of Molecular Biology at Paranaense University, cryopreserved by the wheat grain technique, ${ }^{28,29}$ identified by sequencing the internal transcribed spacers (ITS) of ribosomal DNA, and deposited in the GenBank database (http://www. ncbi.nlm.nih.gov/genbank/) with the accession number MG211674..$^{29}$ The strain was registered in the National System of Genetic Patrimony Management and Associated Traditional Knowledge (SisGen, its acronym in Portuguese) under the code A04E776. The fungus was cultivated in a $\%$ malt extract agar (MEA) substrate at $25 \pm 1{ }^{\circ} \mathrm{C}$ for seven days, and the colonies without sectioning and with mycelial growth vigor were selected as the inoculum of wheat grains. Wheat grains cooked at $90{ }^{\circ} \mathrm{C}$ in ultrapure water for $40 \mathrm{~min}$ were used. After cooking, the excess water was removed and $1 \mathrm{~g}$ of calcium carbonate $\left(\mathrm{CaCO}_{3}\right)$ was added to every $100 \mathrm{~g}$ of grains. The grains were transferred to polypropylene bags and autoclaved at $121^{\circ} \mathrm{C}$ for $1 \mathrm{~h}$ and $30 \mathrm{~min}$. After cooling, MEA disks containing mycelia were transferred to the bags with grains and incubated at $25 \pm 1{ }^{\circ} \mathrm{C}$ until complete colonization. ${ }^{30}$ The colonized wheat grains were utilized as inoculum on the cultivation substrate.

\subsection{Cultivation substrate for mushroom production}

Sugarcane bagasse and rice husks from a sugarcane processing mill and from a rice mill, respectively, were utilized with a $1: 1$ $(\mathrm{v}: \mathrm{v})$ proportion to compose the cultivation substrate with 10 replications. Each replication was represented by a polypropylene bag with $2 \mathrm{~kg}$ of the cultivation substrate autoclaved for $1 \mathrm{~h}$ and $30 \mathrm{~min}$ at $121{ }^{\circ} \mathrm{C}$. To each bag was added $20 \mathrm{~g}$ of wheat grains containing fungus, thermosealed, and stored in a cultivation room with temperature control at $27 \pm 1^{\circ} \mathrm{C}$ and $80 \%$ air humidity until complete substrate colonization. After 30 days, the top part of the bags was opened, and room temp- erature was reduced to $18 \pm 1{ }^{\circ} \mathrm{C}$ for $24 \mathrm{~h}$ (thermal shock). The basidiocarp harvesting was performed daily when the pileus edge was flat, indicating growth completion and senescence process onset. The harvested basidiocarps (stipe and pileus together) were dehydrated in an air circulating oven at $60{ }^{\circ} \mathrm{C}$ for $24 \mathrm{~h}$, ground in a mortar with a pestle to obtain granulometry $\leq 0.35 \mathrm{~mm}$ (48 mesh) and stored at $-20{ }^{\circ} \mathrm{C}$ for subsequent analyses.

\subsection{Chemical composition of the basidiocarp}

2.3.1 Macronutrient composition and energetic value. The proximate composition (protein, fat, ash, and carbohydrate content) of the samples was determined according to standard procedures. $^{31}$ The crude protein content $(N \times 4.38)$ of the samples was estimated by the macro-Kjeldahl method; crude fat was determined by extracting a known mass of the powdered sample with petroleum ether, using a Soxhlet apparatus; the ash content was determined by incineration at $600 \pm 15^{\circ} \mathrm{C}$. Total carbohydrates were calculated by difference [total carbohydrates (g per $100 \mathrm{~g}$; dry basis $\left.)=100-\left(g_{\text {protein }}+g_{\text {fat }}+g_{\text {ash }}\right)\right]$. The energy was calculated according to Regulation (EC) number 1169/2011 of the European Parliament and of the Council $^{32}$ on the Provision of Food Information to Consumers, as: energy [(kcal per $100 \mathrm{~g}$; dry basis $)=4 \times\left(g_{\text {protein }}+g_{\text {carbohy- }}\right.$ drates $\left.)+9 \times\left(g_{\text {fat }}\right)\right]$.

\subsubsection{Hydrophilic compounds}

Soluble sugars. The dried samples $(1 \mathrm{~g})$ were spiked with raffinose as the internal standard (IS, $25 \mathrm{mg} \mathrm{mL}^{-1}$ ) and extracted with $40 \mathrm{~mL}$ of $80 \%$ aqueous ethanol at $80^{\circ} \mathrm{C}$ for $1 \mathrm{~h}$. The resulting suspension was centrifuged ( $15000 \mathrm{~g}$ for $10 \mathrm{~min}$ ). The resulting suspension was filtered and concentrated under reduced pressure (rotary evaporator Büchi R-210, Flawil, Switzerland) and defatted three times with $10 \mathrm{~mL}$ of diethyl ether. After concentration at $\approx 40{ }^{\circ} \mathrm{C}$, the solid residues were dissolved in water to a final volume of $5 \mathrm{~mL}$ and filtered through $0.2 \mu \mathrm{m}$ disposable LC nylon disk filters and transferred into an injection vial to be analyzed by high performance liquid chromatography (HPLC). The soluble sugars present in L. crinitus basidiocarp were analyzed by HPLC using a refraction index (RI) detector. The HPLC equipment consisted of an integrated system with a pump (Knauer, Smartline system 1000, Berlin, Germany), degasser system (Smartline manager 5000), autosampler (AS-2057 Jasco, Easton, MD, USA) and an RI detector (Knauer Smartline 2300). Data were analyzed using Clarity 2.4 software (DataApex). The chromatographic separation was achieved with a Eurospher 100-5 $\mathrm{NH}_{2}$ column $(4.6 \times 250 \mathrm{~mm}, 5 \mathrm{~mm}$, Knauer $)$ operating at $30{ }^{\circ} \mathrm{C}$ (7971 R Grace oven). The mobile phase was acetonitrile: deionized water, $70: 30(\mathrm{v}: \mathrm{v})$ at a flow rate of $1 \mathrm{~mL} \mathrm{~min}^{-1}$. The compounds were identified by chromatographic comparisons with authentic standards. The quantification was performed using the internal standard method. ${ }^{33}$ The results were expressed in $\mathrm{g}$ per $100 \mathrm{~g}$ (dry basis).

Organic acids. Samples (approximately $1.5 \mathrm{~g}$ ) were extracted using $25 \mathrm{~mL}$ of meta-phosphoric acid $\left(25^{\circ} \mathrm{C}\right.$ at $\left.150 \mathrm{rpm}\right)$ by stirring for $45 \mathrm{~min}$ and subsequently filtered through filter 
paper (Whatman ${ }^{\circledR}$ grade 4 ). Before analysis, the sample was filtered through $0.2 \mu \mathrm{m}$ nylon filters. ${ }^{34}$ The organic acid profile of the studied samples was determined according to a previously described procedure. ${ }^{34}$ The analysis was performed by ultra-fast liquid chromatography (UFLC), coupled to a photodiode array detector (PDA), following the previously mentioned procedure. The analysis was performed using a Shimadzu 20A series UFLC (Shimadzu Corporation, Kyoto, Japan). Separation was achieved on a SphereClone (Phenomenex, Torrance, CA, USA) reverse phase C18 column ( $5 \mu \mathrm{m}, 250 \mathrm{~mm}, 4.6 \mathrm{~mm}$ i.d.) thermostatted at $35^{\circ} \mathrm{C}$. The elution was performed with sulfuric acid $(3.6 \mathrm{mM})$ using a flow rate of $0.8 \mathrm{~mL} \mathrm{~min}^{-1}$. Detection was carried out in a PDA, using $215 \mathrm{~nm}$ and $245 \mathrm{~nm}$ (for ascorbic acid) as preferred wavelengths. The found organic acids were quantified by comparing the area of their peaks recorded at $215 \mathrm{~nm}$ (245 $\mathrm{nm}$ for ascorbic acid) to calibration curves obtained from commercial standards of each compound. The results were expressed in mg per $100 \mathrm{~g}$ (dry basis).

Phenolic acids and related compounds. The dried samples (approximately $1 \mathrm{~g}$ ) were extracted using $30 \mathrm{~mL}$ of aqueous methanol $(80: 20 ; \mathrm{v}: \mathrm{v})$ by magnetic stirring $\left(25^{\circ} \mathrm{C}, 150 \mathrm{rpm}\right)$ for $1 \mathrm{~h}$, and subsequently filtered (Whatman ${ }^{\circledR}$ grade 4 filter paper) obtaining a hydromethanolic extract. The extraction procedure was repeated with an additional portion of the solvent, repeating the previous process. The obtained extracts were combined, the methanol was evaporated (rotary evaporator previously referred) and the residual aqueous phase was frozen and lyophilized. ${ }^{35}$ After lyophilization, the dried extract was dissolved in aqueous methanol $(20: 80 ; \mathrm{v}: \mathrm{v})$ obtaining a $20 \mathrm{mg} \mathrm{mL} \mathrm{m}^{-1}$ final concentration, filtered through a $0.2 \mu \mathrm{m}$ nylon filter and analyzed by UFLC. The phenolic acid determination was performed using the UFLC system mentioned before for organic acid determinations. Detection was carried out in the PDA (photodiode-array detection), using $280 \mathrm{~nm}$ as the preferred wavelength and in a mass spectrometer (MS) connected to a HPLC system via the PDA cell outlet. The phenolic compounds were identified by comparing their retention times, UV-Vis and mass spectra with those obtained with standard compounds. For the quantitative analysis, a calibration curve for each available phenolic standard was constructed based on the UV-Vis signal. The results were expressed as $\mu \mathrm{g}$ per $100 \mathrm{~g}$ (dry basis).

\subsubsection{Lipophilic compounds}

Fatty acids. Fatty acids (obtained after Soxhlet extraction) were methylated with $5 \mathrm{~mL}$ of methanol:95\% sulfuric acid: toluene $(2: 1: 1 ; \mathrm{v}: \mathrm{v}: \mathrm{v})$ for approximately $12 \mathrm{~h}$ in a bath at $50{ }^{\circ} \mathrm{C}$ and $160 \mathrm{rpm}$; to obtain phase separation, $3 \mathrm{~mL}$ of deionized water were added; the fatty acid methyl esters (FAME) were recovered by shaking in a vortex with $3 \mathrm{~mL}$ of diethyl ether, and the upper phase was passed through a microcolumn of anhydrous sodium sulfate to eliminate water. The sample was recovered in a vial with Teflon and filtered through a $0.2 \mu \mathrm{m}$ Whatman ${ }^{\circledR}$ nylon filter. ${ }^{36}$ The fatty acid profile of the samples was determined by gas-liquid chromatography with a flame ionization detection (GC-FID)-capillary column. The identification of the different fatty acids was made by compari- son of the relative retention time of FAME peaks from samples with standards. The results were expressed in the relative percentage of each fatty acid.

Tocopherols. Extracts were prepared following a previously described procedure. ${ }^{37}$ Before extraction, samples were added with butylhydroxytoluene (BHT, $100 \mu \mathrm{L}$ ) and spiked with tocol $(250 \mu \mathrm{L})$ as the internal standard (IS) for further chromatographic analysis. Samples $(\approx 500 \mathrm{mg}$ ) were extracted by vortex mixing with methanol ( $4 \mathrm{~mL}$ ) for $1 \mathrm{~min}$; subsequently, hexane $(4 \mathrm{~mL})$ was added and the mixture was vortexed again for one additional minute. Finally, a saturated $\mathrm{NaCl}$ aqueous solution ( $2 \mathrm{~mL}$ ) was added and the mixture was homogenized (1 $\mathrm{min}$ ). After that, samples were centrifuged ( $5 \mathrm{~min}, 4000 \mathrm{~g}$ ), and the upper layer, corresponding to the hexane fraction, was transferred to a $25 \mathrm{~mL}$ amber vial. Samples were re-extracted twice with hexane and the combined extracts were dehydrated with anhydrous sodium sulfate, taken to dryness under a nitrogen stream and stored at $-20{ }^{\circ} \mathrm{C}$. Tocopherol extracts were re-dissolved in $1 \mathrm{~mL}$ of $n$-hexane, filtered $(0.22 \mu \mathrm{m}$ disposable LC filter disk), and transferred to an amber injection vial for chromatographic analysis. The analysis was performed using the same HPLC system described for soluble sugars but coupled to a fluorescence detector. The tocopherol identification was performed by chromatographic comparisons with authentic standards and the quantification was based on the fluorescence signal response of each standard. The results were expressed in $\mu \mathrm{g}$ per $100 \mathrm{~g}$ (dry basis).

\subsection{Biological activities of the basidiocarp}

2.4.1 Extract preparation. The same extraction procedure described for the phenolic compounds was applied for the cytotoxicity and antimicrobial activity assays. After the lyophilization process, the obtained extracts were re-dissolved in: (i) autoclaved distilled water, at $8 \mathrm{mg} \mathrm{mL}^{-1}$, to assess the cytotoxic activity assay; and (ii) $5 \mathrm{~mL}$ per $100 \mathrm{~mL}$ solution of DMSO in distilled water, at $100 \mathrm{mg} \mathrm{mL}^{-1}$, to assess the antimicrobial activity assay. These solutions were diluted successively in order to obtain the concentrations necessary to perform the experimental study.

2.4.2 Cytotoxic activity. Four human tumor cell lines were used, namely HeLa (cervical carcinoma), HepG2 (hepatocellular carcinoma), MCF-7 (breast adenocarcinoma), and NCI-H460 (non-small cell lung cancer). Cells were routinely maintained as adherent cell cultures and treated for $48 \mathrm{~h}$ with the diluted extract solutions. ${ }^{38}$ The adherent cells were fixed by adding cold $10 \%$ trichloroacetic acid (TCA, $100 \mathrm{~mL}$ ) and incubated for $60 \mathrm{~min}$ at $4^{\circ} \mathrm{C}$. Plates were then washed with deionized water and dried; $0.1 \%$ sulforhodamine $\mathrm{B}$ solution $(\mathrm{SRB}, 100 \mathrm{~mL}$ ) in $1 \%$ acetic acid was then added to each plate well and incubated for $30 \mathrm{~min}$ at room temperature. Unbound SRB was removed by washing with $1 \%$ acetic acid. Plates were air-dried, the bound SRB was solubilized with $10 \mathrm{mM}$ tris (200 mL, pH 7.4) and the absorbance was measured at $540 \mathrm{~nm}$. The results were expressed as $\mathrm{GI}_{50}$ values (sample concentration that inhibited $50 \%$ of the net cell growth). Ellipticine was used as a positive control. For the possible 
hepatotoxicity evaluation, a culture cell obtained from porcine liver, designed as PLP2, was used. ${ }^{39}$ The same procedure described above for the SRB assay was performed for the growth inhibition. The results were also expressed as $\mathrm{GI}_{50}$ values.

2.4.3 Antibacterial activity. The antibacterial activity of L. crinitus basidiocarp extract was tested against the following Gram-positive bacteria: Staphylococcus aureus subsp. aureus Rosenbach (ATCC 6538), Bacillus cereus Frankland and Frankland (clinical isolate), Micrococcus luteus (Schroeter) Cohn (ATCC 10240), and Listeria monocytogenes (Murray et al.) Pirie (NCTC 7973), and the following Gram-negative ones: Pseudomonas aeruginosa (Schroeter) Migula (ATCC 27853), Escherichia coli (Migula) Castellani and Chalmers (ATCC 35218), Enterobacter cloacae (Jordan) Hormaeche and Edwards (clinical isolate), and Salmonella enterica subsp. enterica (exKauffmann and Edwards) Le Minor and Popoff serovar Typhimurium (ATCC 13311). The broth microdilution method in 96-well microtiter plates was used. ${ }^{40,41}$ The bacterial suspensions were standardized with sterile saline solution $(0.85 \%)$ until the concentration of $1.0 \times 10^{5} \mathrm{CFU} \mathrm{mL} \mathrm{m}^{-1}$. The prepared inoculums were stored at $4{ }^{\circ} \mathrm{C}$ until their utilization. The extract was dissolved in DMSO solution $\left(50 \mathrm{~mL} \mathrm{~L}^{-1}\right)$ containing $1 \mathrm{mg} \mathrm{mL} \mathrm{m}^{-1}$ polysorbate-80 and added to the wells containing $100 \mu \mathrm{L}$ of LB (Luria Bertani) cultivation medium according to Miller. ${ }^{42}$ Next, the bacterial suspensions at $1.0 \times 10^{5} \mathrm{CFU} \mathrm{mL}^{-1}$ were added until reaching the desired concentrations. The mixtures were deposited in microplates and incubated in a rotary agitator $(160 \mathrm{rpm})$ for $24 \mathrm{~h}$ at $37^{\circ} \mathrm{C}$. The lowest concentrations of the extract that were able to completely inhibit bacterial growth, without visible growth in an optical microscope, were defined as the minimum inhibitory concentrations (MIC). The minimum bactericidal concentration (MBC) was determined by serial sub cultivation in microtiter plates containing $100 \mu \mathrm{L}$ of LB broth ${ }^{41}$ per well and incubated for $24 \mathrm{~h}$. The lowest concentration without bacterial growth was defined as MBC, indicating $99.5 \%$ death of the original inoculum. The optical density of each well was measured at a wavelength of $655 \mathrm{~nm}$ using Microplate Manager 4.0 (Bio-Rad Laboratories) and compared to the blank and the positive control. The antibiotics streptomycin (Sigma P 7794) and ampicillin (Panfarma) ( $1 \mathrm{mg} \mathrm{mL} \mathrm{m}^{-1}$ in sterile saline solution) and the food additives sodium sulfite (E221) and potassium metabisulfite (E224) ${ }^{43}$ from 0.001 to $3.5 \mathrm{mg} \mathrm{mL}^{-1}$ were used as positive controls, and DMSO solution ( $50 \mathrm{~mL} \mathrm{~L}^{-1}$ ) was used as the negative control.

2.4.4 Antifungal activity. The antifungal activity of the basidiocarp extract was evaluated in eight fungi: Aspergillus fumigatus Fresenius (ATCC 1022), Aspergillus niger van Tieghem (ATCC 6275), Aspergillus ochraceus Batista et Maia (ATCC 12066), Aspergillus versicolor (Vuillemin) Tiraboschi (ATCC 11730), Penicillium funiculosum Thom (ATCC 8725), Penicillium ochrochloron Biourge (ATCC 90288), Penicillium verrucosum var. cyclopium (Westling) Samson, Stolk \& Hadlok (food isolate), and Trichoderma viride Pers. (IAM 5061). The microorganisms were kept in $2 \%$ malt agar at $4{ }^{\circ} \mathrm{C}$. ${ }^{44}$ The modified microdilution technique using 96-well microtiter plates was used to assess the antifungal activity of the basidiocarp extract. ${ }^{40,41}$ The fungal spores were washed from the plate surface with a sterile $0.85 \%$ saline solution containing $1 \mathrm{mg} \mathrm{mL}{ }^{-1}$ polysorbate-80. The spore suspension was adjusted with saline solution $(0.85 \%)$ until approximately $1.0 \times 10^{5}$ conidia per $\mathrm{mL}$ for the final volume of $100 \mu \mathrm{L}$ per well and stored at $4{ }^{\circ} \mathrm{C}$ until use. The diluted inoculums were cultivated in $2 \%$ malt extract agar to prove the absence of contamination. The basidiocarp extract was diluted in DMSO solution $\left(50 \mathrm{~mL} \mathrm{~L}^{-1}\right)$ containing $1 \mathrm{mg} \mathrm{mL} \mathrm{m}^{-1}$ polysorbate-80. Each solution with the diluted extract was added to $2 \%$ malt extract medium containing inoculum. The microplates were incubated in a rotary agitator (160 rpm) for $72 \mathrm{~h}$ at $28^{\circ} \mathrm{C}$. The wells with the lowest concentrations of visible extract without growth, but visible under an optical microscope, were defined as the minimum inhibitory concentration (MIC) of the extract. The minimum fungicidal concentration (MFC) was determined by a serial sub cultivation of $2 \mu \mathrm{L}$ of evaluated fungal cultures which were dissolved in culture medium and inoculated in microtiter plates containing $100 \mu \mathrm{L}$ of $2 \%$ malt extract broth per well for $72 \mathrm{~h}$ at $28{ }^{\circ} \mathrm{C}$. The lowest concentration without visible growth under an optical microscope was defined as the MFC, indicating 99.5\% of the original inoculum death. The commercial fungicides bifonazole (Srbolek) and ketoconazole (Zorkapharma, Šabac, Serbia) and the food additives sodium sulfite (E221) and potassium metabisulfite (E224) ${ }^{43}$ from 0.001 to $3.5 \mathrm{mg} \mathrm{mL}^{-1}$ were used as positive controls, and DMSO solution $\left(50 \mathrm{~mL} \mathrm{~L}^{-1}\right)$ was used as the negative control.

\subsection{Experimental design and statistical analysis}

For chemical, cytotoxic, and antimicrobial analyses, three randomly chosen samples were used, and all assays were carried out in triplicate. The results were expressed as arithmetical average \pm standard deviation (SD) and an analysis of variance (ANOVA) was applied, and the typical requirements, homoscedasticity by Levene's test and normal distribution by Shapiro Wilk's test, were preliminarily performed. Welch test was applied to verify the existence of statistically significant differences. The ANOVA results were classified using Tukey HSD (honestly significant difference) test or Tamhane's T2, when homoscedasticity was verified, respectively. All statistical tests were performed at a 5\% significance level using IBM SPSS Statistics for Windows, version 25 (IBM Corporation, New York, USA).

\section{Results}

Regarding the proximate composition, carbohydrates were the most abundant macronutrient compound present in L. crinitus basidiocarp (82.4 g per $100 \mathrm{~g}$ ), followed by proteins (13.0 g per $100 \mathrm{~g})$. Ashes and total fat were part of the minority compounds, obtaining an energy value of $385.4 \mathrm{kcal}$ per $100 \mathrm{~g}$ (Table 1).

Regarding the hydrophilic compounds found in the basidiocarp, the main soluble sugar was trehalose (80\%), followed 
Table 1 Macronutrient composition and energetic value of dried Lentinus crinitus basidiocarp

\begin{tabular}{lc}
\hline Nutrient/energy & Value \\
\hline Ash (g per 100 g) & $4.2 \pm 0.2$ \\
Proteins (g per 100 g) & $13.0 \pm 0.7$ \\
Fat (g per 100 g) & $0.48 \pm 0.03$ \\
Carbohydrates (g per $100 \mathrm{~g})$ & $82.4 \pm 0.4$ \\
Energy (kcal per 100 g) & $385.4 \pm 0.8$
\end{tabular}

Values expressed as arithmetic mean \pm standard deviation (dry basis; $n=3)$.

Table 2 Chemical composition of the hydrophilic extract (sugars, organic acids, and phenolic acids) of Lentinus crinitus basidiocarp

\begin{tabular}{l}
\hline Compound \\
\hline Sugar $(\mathrm{g}$ per $\mathbf{1 0 0} \mathrm{g}$ ) \\
Mannitol \\
Sucrose \\
Trehalose \\
Total soluble sugars \\
Organic acids (mg per $\mathbf{1 0 0} \mathrm{g}$ ) \\
Oxalic acid \\
Malic acid \\
Fumaric acid \\
Total organic acids \\
Phenolic acids $(\boldsymbol{\mu g}$ per $\mathbf{1 0 0} \mathrm{g}$ ) \\
-Hydroxybenzoic acid \\
Cinnamic acid \\
Total phenolic acids
\end{tabular}

Value

$\begin{aligned} 0.18 & \pm 0.01 \\ 0.73 & \pm 0.05 \\ 3.5 & \pm 0.2 \\ 4.4 & \pm 0.3 \\ 132 & \pm 5 \\ 730 & \pm 4 \\ 0.035 & \pm 0.001 \\ 863 & \pm 1 \\ 724 & \pm 12 \\ 05.52 & \pm 0.01 \\ 724 & \pm 12\end{aligned}$

Values expressed as arithmetic mean \pm standard deviation (dry basis; $n=3)$.

by sucrose $(16 \%)$ and mannitol (4\%) (Table 2). The main organic acids were malic acid (84\%), followed by oxalic acid $(15 \%)$ and fumaric acid $(<1 \%)$ (Table 2$)$. The main phenolic acid found was $p$-hydroxybenzoic acid and a precursor of complex phenolic compounds, cinnamic acid (Table 2).

Regarding the lipophilic compounds of the basidiocarp, polyunsaturated fatty acids (PUFA) were the major ones over saturated fatty acids (SFA) and monounsaturated fatty acids (MUFA) (Table 3). Twenty fatty acids were identified in the lipid fraction of the basidiocarp and the major chemical compounds were linoleic (66.4\%), palmitic (11.2\%), and oleic $(9.8 \%)$ acids (Table 3). Also, $\beta$-tocopherol was identified in the basidiocarp at $505 \mu \mathrm{g}$ per $100 \mathrm{~g}$ (Table 3).

The basidiocarp extracts did not show cytotoxicity, since there was no growth inhibition of tumor and non-tumor cell cultures at the tested concentrations $\left(\mathrm{GI}_{50}\right.$ values higher than $400 \mu \mathrm{g} \mathrm{mL} \mathrm{m}^{-1}$; Table 4). These results indicate that L. crinitus is safe for human consumption although, as previously mentioned, it is mostly consumed by Amazonian Indians. ${ }^{9,45}$

The basidiocarp extract of L. crinitus presented bacteriostatic activity against all evaluated bacterial strains. The MIC values for the basidiocarp extract ranged from 0.12 to $0.499 \mathrm{mg} \mathrm{mL}^{-1}$. For the positive controls, they ranged from 0.040 to $0.248 \mathrm{mg} \mathrm{mL}^{-1}$ for streptomycin and from 0.25 to
Table 3 Chemical composition of the lipophilic extract (fatty acids and tocopherols) of Lentinus crinitus basidiocarp

\begin{tabular}{|c|c|}
\hline Compound & Value (\%) \\
\hline Caproic acid (C6:0) & $0.116 \pm 0.005$ \\
\hline Caprylic acid (C8:0) & $0.143 \pm 0.001$ \\
\hline Capric acid (C10:0) & $0.205 \pm 0.004$ \\
\hline Lauric acid (C12:0) & $0.39 \pm 0.01$ \\
\hline Myristic acid (C14:0) & $1.05 \pm 0.03$ \\
\hline Pentadecanoic acid (C15:0) & $1.27 \pm 0.01$ \\
\hline Palmitic acid (C16:0) & $11.23 \pm 0.03$ \\
\hline Palmitoleic acid (C16:1) & $0.32 \pm 0.02$ \\
\hline Heptadecanoic acid (C17:0) & $0.65 \pm 0.05$ \\
\hline Stearic acid (C18:0) & $2.38 \pm 0.02$ \\
\hline Oleic acid $\left(\mathrm{C} 18: 1_{\mathrm{n}-9}\right)$ & $9.8 \pm 0.1$ \\
\hline Linoleic acid $\left(\mathrm{C} 18: 2_{\mathrm{n}-6}\right)$ & $66.4 \pm 0.3$ \\
\hline$\alpha$-Linolenic acid $\left(\mathrm{C} 18: 3_{\mathrm{n}-3}\right)$ & $1.80 \pm 0.01$ \\
\hline Arachidic acid (C20:0) & $0.253 \pm 0.004$ \\
\hline Eicosenoic acid (C20:1) & $0.072 \pm 0.001$ \\
\hline cis-11,14-Eicosadienoic acid (C20:2) & $0.46 \pm 0.01$ \\
\hline $\begin{array}{l}\text { cis-11,14,17-Eicosatrienoic acid and heneicosanoic acid } \\
(\text { C20:3 } 3 \text {-3 }+ \text { C21:0) }\end{array}$ & $0.55 \pm 0.02$ \\
\hline Behenic acid (C22:0) & $2.3 \pm 0.2$ \\
\hline Erucic acid $\left(C 22: 1_{n-9}\right)$ & $0.082 \pm 0.005$ \\
\hline Lignoceric acid (C24:0) & $0.52 \pm 0.01$ \\
\hline Total saturated fatty acids (\% of total fatty acids) & $20.5 \pm 0.2$ \\
\hline $\begin{array}{l}\text { Total monounsaturated fatty acids (\% of total fatty } \\
\text { acids) }\end{array}$ & $10.29 \pm 0.09$ \\
\hline Total polyunsaturated fatty acids ( $\%$ of total fatty acids) & $69.2 \pm 0.3$ \\
\hline Tocopherol & \\
\hline$\beta$-Tocopherol ( $\mu \mathrm{g}$ per $100 \mathrm{~g})$ & $505 \pm 32$ \\
\hline
\end{tabular}

Table 4 Cytotoxic activity of the methanolic extracts of Lentinus crinitus basidiocarp and positive control ellipticine against human tumor cell lines and non-tumor cells

\begin{tabular}{llc}
\hline Cell line & Basidiocarp $\left(\mathrm{GI}_{50} \mu \mathrm{g} \mathrm{mL}^{-1}\right)$ & Ellipticine $\left(\mathrm{GI}_{50} \mu \mathrm{g} \mathrm{mL} \mathrm{mL}^{-1}\right)$ \\
\hline Tumor cell & & \\
HepG2 & $>400$ & $3.2 \pm 0.5$ \\
MCF7 & $>400$ & $0.91 \pm 0.04$ \\
NCI-H460 & $>400$ & $1.42 \pm 0.01$ \\
HeLa & $>400$ & $1.1 \pm 0.2$ \\
& & \\
Non-tumor cell & \\
PLP2 & $>400$ & $2.06 \pm 0.03$
\end{tabular}

Values expressed as arithmetic mean \pm standard deviation (dry basis; $n=3)$. $\mathrm{GI}_{50}=$ extract concentration corresponding to $50 \%$ growth inhibition activity. MCF-7 = breast adenocarcinoma, NCI-H460 = lung carcinoma, HeLa = cervical carcinoma, HepG2 = hepatocellular carcinoma, and PLP2 = primary cell culture obtained from porcine liver.

$0.74 \mathrm{mg} \mathrm{mL}^{-1}$ for ampicillin. Regarding the commercial additives used, MIC values ranged from 1.00 to $3.97 \mathrm{mg} \mathrm{mL}^{-1}$ for E221 and from 0.505 to $2.01 \mathrm{mg} \mathrm{mL}^{-1}$ for E224 (Fig. 1). The basidiocarp extract MIC values were all equal to or lower than the food additive controls (Fig. 1). Only for E. coli the value obtained for the basidiocarp extract was equal to that of E224 


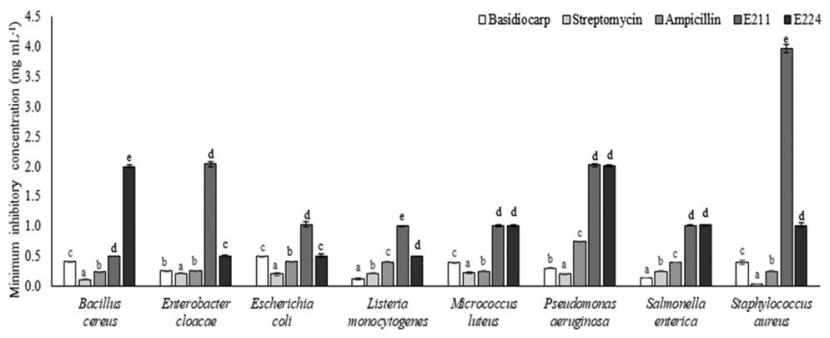

Fig. 1 Minimum inhibitory concentration (MIC) of Lentinus crinitus basidiocarp extract and positive controls streptomycin, ampicillin, sodium sulfite (E221), and potassium metabisulfite (E224). Different letters indicate significant differences among treatments and controls by Tukey's HSD (honestly significant difference) test $(p<0.05)$ (arithmetic mean \pm standard deviation; $n=3$ ).

control (Fig. 1). Regarding the ampicillin and streptomycin controls, the basidiocarp extract had similar or lower MIC values, except for B. cereus, E. coli, M. luteus, and S. aureus which showed higher values, and for $P$. aeruginosa and $E$. cloacae whose values were higher than that of streptomycin control (Fig. 1). These results suggest that the basidiocarp extract is a promising agent to control almost all the tested bacteria with higher activity than the controls.

Noticeably, compared to all controls, the basidiocarp extract was better against $L$. monocytogenes, $P$. aeruginosa, and $S$. enterica. Moreover, for these strains, the basidiocarp extract had an MIC varying from 2.7 to 4.0-fold lower than the ampicillin control, and an MIC varying from 2.5 to 10 -fold lower than the food additive controls.

The basidiocarp extract of $L$. crinitus presented bactericide activity against all evaluated bacterial strains (Fig. 2). The most evident strain inhibition of the basidiocarp extract was against E. coli, L. monocytogenes, M. luteus, P. aeruginosa, S. enterica, and $S$. aureus with the lower MBC values compared to food additive controls (Fig. 2). The MBC values for the basidiocarp extract ranged from 0.248 to $0.604 \mathrm{mg} \mathrm{mL}^{-1}$, and for the positive controls they ranged from 0.102 to $0.50 \mathrm{mg} \mathrm{mL}^{-1}$ for streptomycin and from 0.402 to $1.203 \mathrm{mg} \mathrm{mL} \mathrm{m}^{-1}$ for ampicillin. Regarding the food additives, the $\mathrm{MBC}$ values ranged from

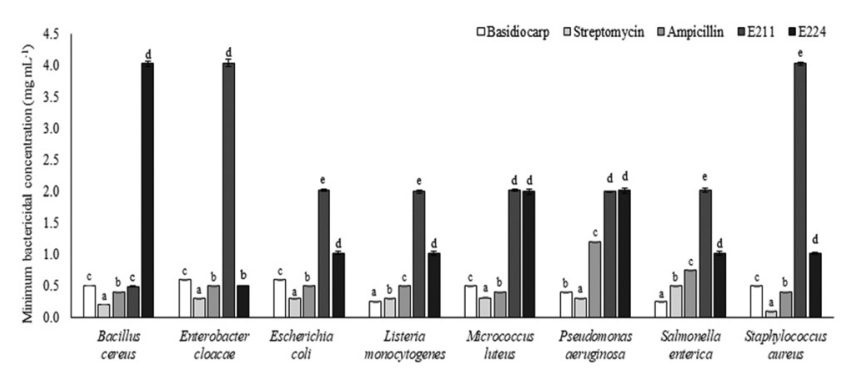

Fig. 2 Minimum bactericidal concentration (MBC) of Lentinus crinitus basidiocarp extract and positive controls streptomycin, ampicillin, sodium sulfite (E221), and potassium metabisulfite (E224). Different letters indicate significant differences among treatments and controls by Tukey's HSD (honestly significant difference) test ( $p<0.05$ ) (arithmetic mean \pm standard deviation; $n=3$ ).
0.497 to $4.04 \mathrm{mg} \mathrm{mL} \mathrm{m}^{-1}$ for $\mathrm{E} 221$, and from 0.502 to $2.02 \mathrm{mg}$ $\mathrm{mL}^{-1}$ for E224 (Fig. 2). The basidiocarp extract MBC values were all equal to or lower than those of the food additive controls (Fig. 2). Only for B. cereus the basidiocarp extract revealed equal values for E221 control, and for E. cloacae higher values compared to those of E224 control (Fig. 2). The basidiocarp extract presented lower $\mathrm{MBC}$ values against $L$. monocytogenes and $S$. enterica (around $0.25 \mathrm{mg} \mathrm{mL}^{-1}$ for both), values 2.0 and 3.0-fold lower than that for the control ampicillin, respectively, and 4 to 8 -fold lower than that for the food additive controls (Fig. 2). In addition, MBC values were close to the ones for the controls against $M$. luteus and $P$. aeruginosa (Fig. 2). Once again, the results obtained suggest that the basidiocarp extract is a promising agent for controlling most of the studied bacteria. Noticeably, when compared to all controls, the basidiocarp extract was better against $L$. monocytogenes, and $S$. enterica compared with all bacterial strains and controls (Fig. 2). The basidiocarp extract showed bactericidal activity against the other remaining bacteria, but with MBC values, in general, lower than those of the food additive controls and similar to those of the streptomycin and ampicillin controls (Fig. 2).

The basidiocarp extract was effective against all fungal strains showing MIC values ranging from 0.0399 to $0.499 \mathrm{mg}$ $\mathrm{mL}^{-1}$, and for the positive controls the MIC values ranged from 0.0999 to $0.199 \mathrm{mg} \mathrm{mL}^{-1}$ for bifonazole, and from 0.200 to $2.499 \mathrm{mg} \mathrm{mL} \mathrm{m}^{-1}$ for ketoconazole. Regarding food additives, MIC values ranged from 1.01 to $2.03 \mathrm{mg} \mathrm{mL}^{-1}$ for E211, and from 0.500 to $2.01 \mathrm{mg} \mathrm{mL}^{-1}$ for E224 (Fig. 3). The basidiocarp extract had lower MIC values for all fungal strains compared to food additive controls (Fig. 3). For the positive controls ampicillin and streptomycin, the basidiocarp extract presented MIC values that were equal to or lower than the ones for the fungal strains, except against A. fumigatus and A. versicolor, for which it had higher values (Fig. 3).

The MFC of the basidiocarp extract was effective against all fungal strains and ranged from 0.0601 to $0.6004 \mathrm{mg} \mathrm{mL}^{-1}$, and for the positive controls it ranged from 0.198 to $0.2504 \mathrm{mg}$ $\mathrm{mL}^{-1}$ for bifonazole, and from 0.302 to $3.49 \mathrm{mg} \mathrm{mL}^{-1}$ for ketoconazole. Regarding food additives, the MFC ranged from 2.01 to $4.04 \mathrm{mg} \mathrm{mL}^{-1}$ for $\mathrm{E} 211$, and from 0.502 to $2.02 \mathrm{mg} \mathrm{mL}^{-1}$ for

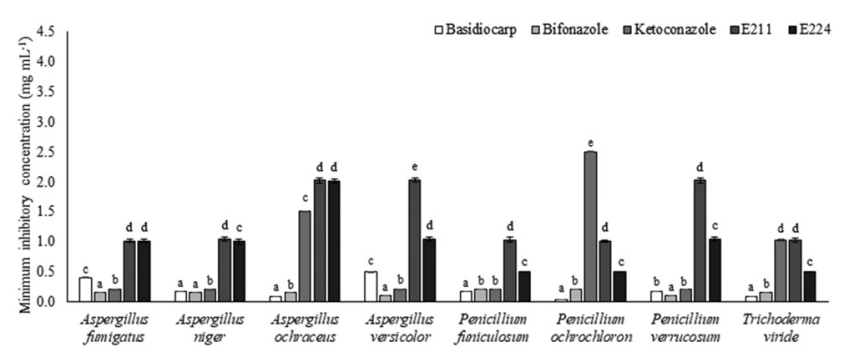

Fig. 3 Minimum inhibitory concentration (MIC) of Lentinus crinitus basidiocarp extract and positive controls bifonazole, ketoconazole, sodium sulfite (E221), and potassium metabisulfite (E224). Different letters indicate significant differences among treatments and controls by Tukey's HSD (honestly significant difference) test $(p<0.05)$ (arithmetic mean \pm standard deviation; $n=3$ ). 


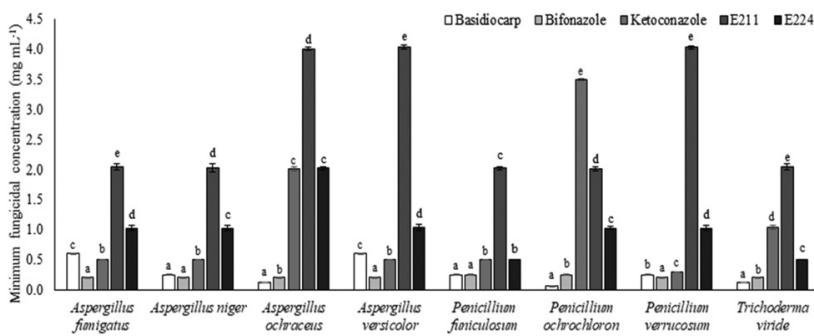

Fig. 4 Minimum fungicidal concentration (MFC) of Lentinus crinitus basidiocarp extract and positive controls bifonazole, ketoconazole, sodium sulfite (E221), and potassium metabisulfite (E224). Different letters indicate significant differences among treatments and controls by Tukey's HSD (honestly significant difference) test $(p<0.05)$ (arithmetic mean \pm standard deviation; $n=3$ ).

E224 (Fig. 4). The MFC values of the basidiocarp extract were all lower than those of the food additive controls. The basidiocarp extract presented lower MFC values against A. ochraceus, $P$. ochrochlorum, and T. viride when compared to all controls. For A. niger and $P$. funiculosum, the basidiocarp extract MFC values did not differ from that of bifonazole control and were only 2.0-fold lower than that of ketoconazole control. However, the values were lower for both fungal strains when compared to food additive controls, which indicates the high efficiency of the basidiocarp extract. For A. versicolor and A. fumigatus, MFC values of basidiocarp extract were higher than those of bifonazole and ketoconazole controls but still lower than those of E221 and E224 controls.

Overall, the basidiocarp extract presented bacteriostatic and bactericide activity against all the studied bacteria with better MIC and MBC values than most controls (Fig. 1 and 2), and also fungistatic and fungicide activity against all the fungi tested, with better MIC and MFC values than most controls (Fig. 3 and 4). Therefore, the L. crinitus basidiocarp extract has potential utilization for controlling important microorganisms in food and health.

\section{Discussion}

Edible mushrooms have good nutritional quality, especially proteins, fibers, and also bioactive compounds like polyphenols. ${ }^{46,47}$ Our study showed that L. crinitus basidiocarp is a good source of carbohydrates and proteins, having a lowfat content, as reported for other mushrooms. ${ }^{3,47,47}$ Thus, as all these studies suggest, mushrooms are a good option for inclusion in low-calorie diets. ${ }^{49}$

The protein content values of $L$. crinitus basidiocarp reported in previous studies was $9.8 \mathrm{~g}$ per $100 \mathrm{~g}$ (original value converted by 4.38 factor), ${ }^{17} 10.1 \mathrm{~g}$ per $100 \mathrm{~g}$ (original value converted by 4.38 factor), ${ }^{18}$ and $27.0 \mathrm{~g}$ per $100 \mathrm{~g} .{ }^{16}$ Our results showed that the protein content ( $13.0 \mathrm{~g}$ per $100 \mathrm{~g}$ ) is similar to those found in the literature for this fungus. Chang and Miles ${ }^{50}$ reported that edible mushrooms normally contain 19.0 to $35.0 \mathrm{~g}$ per $100 \mathrm{~g}$ protein (dry basis) and Kalač ${ }^{3}$ reported that that of wild-growing mushrooms ranged from 13.2 to $62.8 \mathrm{~g}$ per $100 \mathrm{~g}$. Therefore, we can conclude that the values obtained for the protein content of $L$. crinitus are slightly below the range reported in the literature for this type of food. However, compared to other foods, the protein levels of this mushroom are similar to the levels found in eggs (13.0 g per $100 \mathrm{~g}$ ) and are even higher than those found in raw rice (7.3 $\mathrm{g}$ per $100 \mathrm{~g}$ ) or wheat flour (9.8 $\mathrm{g}$ per $100 \mathrm{~g}) .^{51}$

Trehalose is the main oligosaccharide in mushrooms ranging from 0.21 to $42.8 \mathrm{~g}$ per $100 \mathrm{~g}$ with the median from 3.8 to $4.0 \mathrm{~g}$ per $100 \mathrm{~g}$ for wild collected mushrooms, ${ }^{3,52}$ and from 0.23 to $72.8 \mathrm{~g}$ per $100 \mathrm{~g}$ with a median of $2.63 \mathrm{~g}$ per $100 \mathrm{~g}$ for commercial cultivated mushrooms. ${ }^{3}$ For $L$. crinitus basidiocarp, in our study, trehalose (3.5 g per $100 \mathrm{~g}$ ) was the most abundant soluble sugar and it had a similar content compared to most basidiomycetes reported in the literature. Trehalose has effects on metabolic pathways such as modulating glucose homeostasis, improving beta cell function, reducing postprandial insulin release, and lipid profile. ${ }^{53-55}$ In addition, trehalose migrates from mycelia to basidiocarps and protects the cells against stresses such as desiccation, temperature, and oxygen pressures. ${ }^{56,57}$ This oligosaccharide may also be related to L. crinitus enzymatic activity ${ }^{29}$ and mycelial biomass production, mainly at extreme temperatures $\left(19\right.$ to $\left.40{ }^{\circ} \mathrm{C}\right)$ and $\mathrm{pH}$ (2.5 to 10 ) conditions. ${ }^{58}$

Edible mushroom fat contents were reported from 1.1 to $8.3 \mathrm{~g}$ per $100 \mathrm{~g} .{ }^{50}$ For L. crinitus basidiocarp cultivated in a substrate based on Theobroma grandiflorum exocarp, the fat content ranged from 3.3 to $4.5 \mathrm{~g}$ per $100 \mathrm{~g}$ (ref. 16) and was $1.5 \mathrm{~g}$ per $100 \mathrm{~g}$ for wild $L$. crinitus basidiocarp collected in the Brazilian Cerrado. ${ }^{17}$ In our study, the basidiocarp had a lower fat content ( $0.48 \mathrm{~g}$ per $100 \mathrm{~g}$ ) compared with wild and cultivated $L$. crinitus basidiocarp or other mushrooms. Moreover, the $L$. crinitus basidiocarp from our study had the lowest value of total monounsaturated fatty acids $(10.3 \%$ of total fatty acids) and the highest value of total polyunsaturated fatty acids (69.2\% of total fatty acids), the major compound being linoleic acid (C18:2 $\left.2_{n-6}\right)$ followed by oleic acid (C18:1 $\left.1_{n-9}\right)$ and $\alpha$-linolenic acid $\left(\mathrm{C} 18: 3_{\mathrm{n}-3}\right)$. Oleic acid (omega-9) may reduce the risk of coronary artery diseases. ${ }^{59}$ Linoleic acid (omega-6), considered an essential fatty acid that cannot be synthesized by the human body, is a precursor of arachidonic acid which plays an important role in inflammatory processes, ${ }^{60}$ and has a significant role in health because it lowers cholesterol and triglycerides. ${ }^{61}$ $\alpha$-Linolenic acid is also an essential fatty acid which showed physiological benefits in humans such as brain development, anti-inflammatory activity, and cardiovascular health improvement. $^{62-65}$

Tocopherols are known natural antioxidant compounds ${ }^{66}$ with anti-inflammatory and anticancer properties with peroxidation prevention in cellular membrane phospholipids. ${ }^{67}$ In our study, $\beta$-tocopherol (505 $\mu \mathrm{g}$ per $100 \mathrm{~g}$ ) was the only vitamin identified. The majority of mushrooms (seven out of eight) studied by Barros et al. ${ }^{49}$ had lower levels of $\beta$-tocopherol (3 to $193 \mu \mathrm{g}$ per $100 \mathrm{~g}$ ) than L. crinitus; only one (Boletus edulis) had a higher $\beta$-tocopherol content $(890 \mu \mathrm{g}$ per $100 \mathrm{~g})$. Toledo 
et $a l .{ }^{52}$ reported that among nine wild mushrooms, four had 12.36 to $59.03 \mu \mathrm{g}$ per $100 \mathrm{~g} \beta$-tocopherol but it was not detectable in five mushroom species. Wild mushrooms (fourteen out of eighteen) studied by Heleno et $a l^{37}$ had lower levels of $\beta$-tocopherol (7 to $386 \mu \mathrm{g}$ per $100 \mathrm{~g}$ ), only one (Laccaria laccata) showed higher levels (706 $\mu \mathrm{g}$ per $100 \mathrm{~g}$ ) than L. crinitus, but it was not detected in three species. This suggests that $L$. crinitus basidiocarp has high $\beta$-tocopherol levels compared with the average values reported in the literature.

For hydrophilic compounds, malic acid has been reported with values of $130 \mathrm{mg}$ per $100 \mathrm{~g}$ for Agaricus bisporus and is absent for Agaricus brasiliensis. ${ }^{48}$ Oxalic acid, another hydrophilic compound, has been reported with values of $580 \mathrm{mg}$ per $100 \mathrm{~g}$ for A. bisporus $^{48}$ and $115 \mathrm{mg}$ per $100 \mathrm{~g}$ for A. brasiliensis. ${ }^{68}$ This indicates that the values for malic (730 mg per $100 \mathrm{~g}$ ) and oxalic (132 mg per $100 \mathrm{~g}$ ) acids of our study are among the highest reported levels. These organic acids have a considerable effect on the taste and acceptability of mushrooms and can play a biological role in health due to their potential antioxidant activity. ${ }^{68}$ In addition, oxalic acid has antibacterial activity. ${ }^{69}$

Phenolic compounds are one of the most important groups of secondary metabolites found in mushrooms ${ }^{66}$ that exhibit antioxidant capacity and provide protection against disorders with anticancer, cardioprotective, anti-inflammatory, antithrombotic, and vasodilator activities. ${ }^{66,70-72}$ The main phenolic acid found in our study was $p$-hydroxybenzoic acid $(724 \mu \mathrm{g}$ per $100 \mathrm{~g})$. Other studies reported values of 10,156 , and $157 \mu \mathrm{g}$ per $100 \mathrm{~g}$ for commercial mushrooms such as Pleurotus eryngii, Pleurotus ostreatus, and Lentinula edodes, ${ }^{73}$ respectively, and from 469 to $2407 \mu \mathrm{g}$ per $100 \mathrm{~g}$ (mean of $1304 \mu \mathrm{g}$ per $100 \mathrm{~g}$ ) for eight edible commercial mushrooms, ${ }^{46}$ and from $0 \mu \mathrm{g}$ to $23870 \mu \mathrm{g}$ per $100 \mathrm{~g}$ (mean of $3358 \mu \mathrm{g}$ per $100 \mathrm{~g}$ ) for wild mushrooms, ${ }^{74}$ but it was not found for A. bisporus commercial mushroom. ${ }^{73}$ This indicates that the $p$-hydroxybenzoic acid value found in $L$. crinitus basidiocarp in our study had an intermediary value among the ones reported in the literature. Since the bioactivities (e.g. antioxidant and antimicrobial activity) of organic acids and specifically phenolic compounds are related to the response to stress conditions (abiotic, edaphoclimatic, or production conditions), ${ }^{75}$ this may justify the greater or lesser differences among values for different species, as well as the absence of any compound.

The antimicrobial activity of the L. crinitus basidiocarp extract was verified against all the studied bacterial and fungal strains, showing a broad action spectrum. The antibacterial activity of $P$. ostreatus and $L$. edodes basidiocarp extracts has been reported against $S$. aureus, B. subtilis, $E$. coli, $P$. aeruginosa, and $S$. enterica with MIC values varying from 2.0 to $8.0 \mathrm{mg} \mathrm{mL}{ }^{-1} \cdot{ }^{76}$ Methanolic extracts of A. brasiliensis and A. bisporus were tested against the same bacterial strains used in our study, revealing MIC values ranging from 0.1 to $2.30 \mathrm{mg}$ $\mathrm{mL}^{-1}$ and 0.3 to $1.15 \mathrm{mg} \mathrm{mL}^{-1}$, respectively, and $\mathrm{MBC}$ values ranging from 0.3 to $4.60 \mathrm{mg} \mathrm{mL}^{-1}$ and from 0.3 to $4.70 \mathrm{mg}$ $\mathrm{mL}^{-1}$, respectively. ${ }^{48}$ P. ostreatus, L. edodes, and A. bisporus were tested against $E$. coli and $P$. aeruginosa showing MIC values higher than $20 \mathrm{mg} \mathrm{mL}^{-1} ;^{77}$ and $L$. edodes was tested against $B$. cereus, $S$. aureus, and $E$. coli revealing MIC values ranging from 1.56 to $100 \mathrm{mg} \mathrm{mL}{ }^{-1}{ }^{78}$ Our results for the L. crinitus basidiocarp extract presented MIC values ranging from 13 to 200 -fold higher activity than the values reported in the literature for the same bacteria with bacteriostatic activity. In addition, this extract presented $\mathrm{MBC}$ values ranging from 2.0 and 9.0-fold higher activity than the values reported in the literature for the same bacteria with bactericidal activity. On the other hand, for the $A$. brasiliensis ethanolic extract, the most sensitive bacteria were $S$. aureus and B. cereus with MIC values of 0.08 and $0.04 \mathrm{mg} \mathrm{mL}^{-1}$ and MBC of 0.20 and $0.08 \mathrm{mg} \mathrm{mL}^{-1}$, respectively, ${ }^{48}$ showing higher activity than those in our studies (MIC 0.40 and MBC $0.50 \mathrm{mg} \mathrm{mL}^{-1}$ ) for both species, respectively. However, in our study L. crinitus showed antibacterial activity with MIC and MBC values, respectively, ranging from 4.2 to 9.5 and 2.0 to 6.7fold lower than those of the food additive controls and similar to some antibiotic controls, and the mushroom extract has stronger bacteriostatic and bactericidal activities than streptomycin and ampicillin against $L$. monocytogenes and $S$. enterica.

The antifungal activity of $P$. ostreatus basidiocarp extracts expressed as the MIC value has been reported as $12 \mathrm{mg} \mathrm{mL} \mathrm{L}^{-1}$ against $A$. niger and $16 \mathrm{mg} \mathrm{mL}^{-1}$ against $P$. funiculosum, but no activity was observed against $A$. fumigatus and T. viride. ${ }^{79}$ The extract of $A$. brasiliensis basidiocarp presented an MIC of $0.15 \mathrm{mg} \mathrm{mL}$ and MFC of $1.15 \mathrm{mg} \mathrm{mL}^{-1}$ against A. versicolor, ${ }^{48}$ and the $1 \mathrm{mg} \mathrm{mL}{ }^{-1}$ hydroalcoholic extract of L. crinitus basidiocarp presented 50\% mycelial growth inhibition of Fusarium sp. conidia. ${ }^{19}$ Ganoderma lucidum against the same fungal strains used in our study revealed MIC values from 0.005 to $1.5 \mathrm{mg} \mathrm{mL} \mathrm{mL}^{-1}$ and MFC from 0.1 to $4.5 \mathrm{mg}$ $\mathrm{mL}^{-1}{ }^{80}$ The basidiocarp extract of L. crinitus, in our study, had MIC values 3.7 to 8.8 -fold lower than that of G. lucidum extract for the same fungal strains, ${ }^{80}$ and for A. versicolor, T. viride, and $P$. funiculosum had 15 and 19-fold lower values of MIC and MFC than those for $L$. crinitus. Moreover, L. crinitus had, respectively, MIC and MFC values 2.5 to 25.2- and 3.4 to 33.6fold lower than the ones of food additive and antibiotic controls evaluated in our study. In addition, L. crinitus was more effective than bifonazole and ketoconazole against A. ochraceus, P. ochrochloron, and T. viride. Thus, our results make evident the antifungal potential of $L$. crinitus, which presents a broad action spectrum against infectious fungi and mainly foodborne diseases related to fungi in food.

The antimicrobial activity of basidiomycetes may be related to several chemical compounds such as terpenes, organic acids, phenolic compounds, and steroids among others. ${ }^{8,80-83}$ The acids $p$-hydroxybenzoic and cinnamic had MIC values from 0.003 to $0.12 \mathrm{mg} \mathrm{mL}^{-1}$ and from 0.007 to $0.03 \mathrm{mg} \mathrm{mL}^{-1}$, respectively, against A. fumigatus, A. versicolor, A. ochraceus, A. niger, T. viride, $P$. funiculosum, $P$. ochrochloron, and P. verrucosum. ${ }^{80}$ In addition, $p$-hydroxybenzoic acid has been indicated as an antimicrobial agent against bacteria and fungi. ${ }^{84}$ Other compounds such as malic and oxalic acids are food safety additives ${ }^{85}$ and have been reported as having antimicrobial activity. Malic acid was reported with antimicrobial activity against $E$. coli, L. monocytogenes, ${ }^{86,87}$ Salmonella enteri- 
tidis ${ }^{86}$ and Salmonella gaminara. ${ }^{87}$ Oxalic acid was reported with antimicrobial activity against E. coli. ${ }^{88}$ In our study, L. crinitus showed several major bioactive compounds such as $p$-hydroxybenzoic, cinnamic, $\beta$-tocopherol, linoleic, malic, and oxalic acids that may still be acting synergistically toward antimicrobial activity. The antimicrobial activity might be related to the ability of linoleic acid to break bacterial cell membranes; ${ }^{89}$ the phenolic acid compounds to destabilize the bacterium cytoplasmic membrane, altering the plasma permeability and inhibiting extracellular microbial enzymes; ${ }^{90}$ and the non-dissociated form of organic acid penetration into cells ensuing cytoplasm acidification. ${ }^{91}$

Our study suggests that $L$. crinitus basidiocarp - a mushroom mainly consumed by Amazonian ethnic groups ${ }^{9}$ - presents nutritional and nutraceutical compounds, high antimicrobial activity, and no cytotoxicity, which makes it a potential candidate for mushroom industrial production.

\section{Conclusions}

L. crinitus basidiocarp has considerably high levels of carbohydrates, energy, soluble sugars, $\beta$-tocopherol, phenolic acids (mainly $p$-hydroxybenzoic acid), and organic acids (mainly malic and oxalic acids). The predominant lipophilic compounds are polyunsaturated fatty acids, mainly linoleic (66.4\%), palmitic (11.2\%), and oleic $(9.8 \%)$ acids. The basidiocarp extract has no cytotoxic activity against human tumor cell lines HeLa, HepG2, MCF-7, and NCI-H460, as well as against PLP2 non-tumor cells. The basidiocarp extract has bacteriostatic, bactericidal, fungistatic, and fungicidal activities against all tested microorganisms with MBC and MFC values similar or in several cases significantly lower to those found in commercial antibiotics, and much lower than those found in commercial food additives. Most bactericidal activity is against $L$. monocytogenes and $S$. enterica while the fungicidal activity is mostly against $P$. ochrochloron, followed by $A$. ochraceus and T. viride. This study promotes the consumption of $L$. crinitus basidiocarp that is without toxicity. Its nutritional and bioactive potential has been established and compared with other edible and medicinal mushrooms. Therefore, its consumption, which is mostly made by indigenous populations, can be extended. Moreover, the basidiocarp extract of L. crinitus and its compounds emerge as a potential alternative to the available antimicrobials, having a broad action spectrum. However, the antimicrobial mechanism of action of L. crinitus extract needs to be elucidated along with the compounds responsible for the antimicrobial activity against the tested microorganisms. These results contribute to the development of new studies in which this species may be at the base of the development of new antimicrobial formulations for application in the food, pharmaceutical, and/or agriculture industries.

\section{Conflicts of interest}

There are no conflicts of interest to declare.

\section{Acknowledgements}

The authors thank Paranaense University, Fundação Araucária, Coordenação de Aperfeiçoamento de Pessoal de Nível Superior - Brazil (CAPES) -finance code 001-, and Conselho Nacional de Desenvolvimento Científico e Tecnológico (CNPq) for the financial support and the fellowship. The authors also thank the Foundation for Science and Technology (FCT, Portugal) for financial support through national funds FCT/MCTES to CIMO (UIDB/00690/2020); national funding by FCT, PI, through the institutional scientific employment program-contract for L. Barros's contract, to the project Valor Natural for the contract of F. Reis (Mobilized Project Norte-01-0247FEDER-024479), and the Ministry of Education, Science and Technological Development of Republic of Serbia (451-03-68/ 2020-14/200007).

\section{References}

1 P. M. Kirk, P. Cannon, D. Minter and J. Stalpers, Ainsworth \& Bisby's dictionary of the fungi, $\mathrm{CAB}$ International, Wallingford, UK, 10th edn, 2008.

2 G. Gebreyohannes, A. Nyerere, C. Bii and D. B. Sbhatu, Determination of antimicrobial activity of extracts of indigenous wild mushrooms against pathogenic organisms, J. Evid. Based Complementary Altern. Med., 2019, 2019, 1-7.

3 P. A. Kalač, Review of chemical composition and nutritional value of wild-growing and cultivated mushrooms, J. Sci. Food Agric., 2013, 93(2), 209-218, DOI: 10.1002/ jsfa. 5960 .

4 J. J. Zhang, Y. Li, T. Zhou, D. P. Xu, P. Zhang, S. Li and H. B. Li, Bioactivities and health benefits of mushrooms mainly from China, Molecules, 2016, 21(7), 1-16, DOI: 10.3390/molecules21070938.

5 S. P. Wasser, Medicinal mushroom science: current perspectives, advances, evidences, and challenges, Biomed. J., 2014, 37(6), 345-356, DOI: 10.4103/2319-4170.138318.

6 M. B. D. Bertéli, S. H. Umeo, A. Bertéli, J. S. do Valle, G. A. Linde and N. B. Colauto, Mycelial antineoplastic activity of Agaricus blazei, World J. Microbiol. Biotechnol., 2014, 30(8), 2307-2313, DOI: 10.1007/s11274-014-1656-6.

7 G. T. Silva and T. B. Gibertoni, Aphyllophorales (Basidiomycota) em áreas urbanas da região metropolitana do Recife, PE, Brasil, Hoehnea, 2006, 33(4), 533-543.

8 W. R. Abraham and D. Abate, Antimicrobial metabolites from Lentinus crinitus, J. Antibiot., 1994, 47(11), 1348-1350, DOI: 10.7164 /antibiotics.47.1348.

9 R. Vargas-Isla, N. K. Ishikawa and V. Py-Daniel, Contribuições etnomicológicas dos povos indígenas da Amazônia, Biota Amazônia, 2013, 3, 58-65, DOI: 10.18561/ 2179-5746/biotaamazonia.v3n1p58-65.

10 S. H. Umeo, G. P. N. Souza, P. M. Rapachi, D. M. Garcia, L. D. Paccola-Meirelles, J. S. Valle, N. B. Colauto and G. A. Linde, Screening of basidiomycetes in submerged cul- 
tivation based on antioxidant activity, Genet. Mol. Res., 2015, 14(3), 9907-9914, DOI: 10.4238/2015.August.19.25.

11 M. G. I. Faria, J. S. Valle, A. D. Lopes, A. C. Gonçalves, D. C. Dragunski, N. B. Colauto and G. A. Linde, Bioaccumulation of lithium $\left(\mathrm{Li}_{2} \mathrm{CO}_{3}\right)$ in mycelia of the culinary-medicinal oyster mushroom, Pleurotus ostreatus (Agaricomycetes), Int. J. Med. Mushrooms, 2018, 20(9), 901907, DOI: 10.1615/IntJMedMushrooms.2018027343.

12 M. G. I. Faria, K. V. Avelino, J. S. Valle, G. J. Silva, A. C. Gonçalves, D. C. Dragunski, N. B. Colauto and G. A. Linde, Lithium bioaccumulation in Lentinus crinitus mycelial biomass as a potential functional food, Chemosphere, 2019, 235, 538-542.

13 M. F. Tavares, K. V. Avelino, N. L. Araújo, R. A. Marim, G. A. Linde, N. B. Colauto and J. S. Valle, Decolorization of azo and anthraquinone dyes by crude laccase produced by Lentinus crinitus in solid state cultivation, Braz. J. Microbiol., 2020, 51(1), 99-106, DOI: 10.1007/ s42770-019-00189-w.

14 E. Caroline, D. M. Brito, I. Rodrigo, S. Braga, M. Francisca, S. Teixeira, I. I. Salomão and R. Martim, Production and partial characterization of aspartic proteases synthesized by Lentinus crinitus (L.) Fr. 1825 DPUA 1693 (Polyporaceae), Bol. Mus. Para. Emílio Goeldi. Cienc. Nat., 2019, 1693, 463472.

15 G. Cambri, M. M. L. De Sousa, D. D. M. Fonseca, F. Marchini, J. L. M. Da Silveira and J. Paba, Analysis of the biotechnological potential of a Lentinus crinitus isolate in the light of its secretome, J. Proteome Res., 2016, 15(12), 4557-4568.

16 A. R. G. Machado, M. F. S. Teixeira, L. de Souza Kirsch, M. da C. L. Campelo and I. M. de Aguiar Oliveira, Nutritional value and proteases of Lentinus citrinus produced by solid state fermentation of lignocellulosic waste from tropical region, Saudi J. Biol. Sci., 2016, 23(5), 621-627, DOI: 10.1016/j.sjbs.2015.07.002.

17 C. M. Silva Neto, D. S. Pinto, L. A. C. Santos and F. J. S. Calaça, Bromatological aspects of Lentinus crinitus mushroom (Basidiomycota: Polyporaceae) in agroforestry in the cerrado, Food Sci. Technol., 2019, 2061, 1-6, DOI: 10.1590/fst.14719.

18 G. L. R. Dávila, A. W. Murillo, F. C. J. Zambrano, M. H. Suárez and A. J. J. Méndez, Evaluation of nutritional values of wild mushrooms and spent substrate of Lentinus crinitus (L.) Fr., Heliyon, 2020, 6(3), e03502, DOI: 10.1016/j. heliyon.2020.e03502.

19 A. Figueiredo and A. C. Silva, Atividade "in vitro" de extratos de Pycnoporus sanguineus e Lentinus crinitus sobre o fitopatógeno Fusarium sp., Acta Amazonica, 2014, 44(1), 1-8, DOI: 10.1590/S0044-59672014000100001.

20 T. Bintsis, Foodborne pathogens, AIMS Microbiol., 2017, 3(3), 529-563, DOI: 10.3934/microbiol.2017.3.529.

21 A. M. Pisoschi, A. Pop, C. Georgescu, V. Turcuş, N. K. Olah and E. Mathe, An Overview of natural antimicrobials role in food, Eur. J. Med. Chem., 2018, 143, 922-935, DOI: 10.1016/ j.ejmech.2017.11.095.
22 WHO - WHO estimates of the global burden of foodborne diseases: foodborne disease burden epidemiology reference group 2007-2015. https:/apps.who.int/iris/bitstream/ handle/10665/199350/9789241565165_eng.pdf?sequence=

1, accessed 19 march 2020.

23 Z. Pang, R. Raudonis, B. R. Glick, T. J. Lin and Z. Cheng, Antibiotic resistance in Pseudomonas aeruginosa: mechanisms and alternative therapeutic strategies, Biotechnol. Adv., 2019, 37(1), 177-192, DOI: 10.1016/j. biotechadv.2018.11.013. Epub 2018 Nov 27. PMID: 30500353.

24 A. N. Olaimat, M. A. Al-Holy, H. M. Shahbaz, A. A. AlNabulsi, M. H. A. Ghoush, T. M. Osaili, M. M. Ayyash and R. A. Holley, Emergence of antibiotic resistance in Listeria monocytogenes isolated from food products: a comprehensive review, Compr. Rev. Food Sci. Food Saf., 2018, 17, 12771292.

25 T. F. El-Arabi and M. W. Griffiths, Bacillus cereus, in Foodborne Infections and Intoxications, ed. G. J. Morris and P. M. London, Academic Press, 4th edn, 2013.

26 T. Sultana, J. Rana, S. R. Chakraborty, K. K. Das, T. Rahman and R. Noor, Microbiological analysis of common preservatives used in food items and demonstration of their in vitro anti-bacterial activity, Asian Pac. J. Trop. Dis., 2014, 4(6), 452-456, DOI: 10.1016/S22221808(14)60605-8.

27 R. Gyawali and S. A. Ibrahim, Natural products as antimicrobial agents, Food Control, 2014, 46, 412-429.

28 H. S. Tanaka, M. B. D. Bertéli, F. A. Cordeiro, A. D. Lopes, J. S. Valle, G. A. Linde and N. B. Colauto, Semisolid culture medium improves mycelial recovery of Agaricus subrufescens cryopreserved in cereal grains, Braz. J. Microbiol., 2019, 50(2), 527-532, DOI: 10.1007/s42770-019-00063-9.

29 R. A. Marim, K. V. Avelino, G. A. Linde, N. B. Colauto and J. S. Valle, Lentinus crinitus strains respond differently to cultivation $\mathrm{pH}$ and temperature, Genet. Mol. Res., 2018, 17(1), gmr16039885, DOI: 10.4238/gmr16039885.

30 H. S. Tanaka, T. R. D’A. Mantovani, M. P. Santos, G. A. Linde and N. B. Colauto, Cereal grains and glycerol in Agaricus blazei cryopreservation, Biosci. J., 2013, 29(3), 627633.

31 AOAC - Association of Official Analytical Chemists, Official Methods of Analysis of AOAC International, AOAC INTERNATIONAL, Gaithersburg, 20th edn, 2016.

32 The European Parliament and Council, (2011). Regulation (EC) No. 1169/2011 of the European Parliament and of the Council of 25 October 2011 on the Provision of Food Information to Consumers. Official Journal of the European Union, 304, 22.11.2011: L304/18-L304/63.

33 S. Petropoulos, Â. Fernandes, C. Pereira, N. Tzortzakis, J. Vaz, M. Soković, L. Barros and I. C. F. R. Ferreira, Bioactivities, chemical composition and nutritional value of Cynara cardunculus L. seeds, Food Chem., 2019, 289, 404412, DOI: 10.1016/j.foodchem.2019.03.066.

34 L. Barros, C. Pereira and I. C. F. R. Ferreira, Optimized analysis of organic acids in edible mushrooms from Portugal 
by ultra fast liquid chromatography and photodiode array detection, Food Anal. Methods, 2013, 6(1), 309-316.

35 B. Melgar, M. I. Dias, A. Ciric, M. Sokovic, E. M. GarciaCastello, A. D. Rodriguez-Lopez, L. Barros and I. C. R. F. Ferreira, Bioactive characterization of Persea americana mill. by-products: a rich source of inherent antioxidants, Ind. Crops Prod., 2018, 111, 212-218.

36 F. S. Reis, L. Barros, A. Martins and I. C. F. R. Ferreira, Chemical composition and nutritional value of the most widely appreciated cultivated mushrooms: an inter-species comparative study, Food Chem. Toxicol., 2012, 50(2), 191197.

37 S. A. Heleno, L. Barros, M. J. Sousa, A. Martins and I. C. F. R. Ferreira, Tocopherols composition of Portuguese wild mushrooms with antioxidant capacity, Food Chem., 2010, 119(4), 1443-1450.

38 F. S. Reis, J. C. M. Barreira, R. C. Calhelha, L. J. I. D. Griensven, A. Ćirić, J. Glamočlija, M. Soković and I. C. F. R. Ferreira, Chemical characterization of the medicinal mushroom Phellinus linteus (Berkeley \& Curtis) Teng and contribution of different fractions to its bioactivity, LWT - Food Sci. Technol., 2014, 58(2), 478-485.

39 R. M. V. Abreu, I. C. F. R. Ferreira, R. C. Calhelha, R. T. Lima, M. H. Vasconcelos, F. Adega, R. Chaves and M. J. R. P. Queiroz, Anti-hepatocellular carcinoma activity using human HepG2 cells and hepatotoxicity of 6-substituted methyl 3-aminothieno[3,2-b]Pyridine-2- carboxylate derivatives: in vitro evaluation, cell cycle analysis and QSAR studies, Eur. J. Med. Chem., 2011, 46(12), 5800-5806.

40 H. Hänel and W. A. Raether, More sophisticated method of determining the fungicidal effect of water-insoluble preparations with a cell harvester, using miconazole as an example, Mycoses, 1988, 31(3), 148-154.

41 A. Espinel-Ingroff, Comparison of the E-test with the NCCLS M38-P method for antifungal susceptibility testing of common and emerging pathogenic filamentous fungi, J. Clin. Microbiol., 2001, 39(4), 1360-1367.

42 J. H. Miller, Experiments in molecular genetics, Cold Spring Harbor Laboratory, Cold spring Harbor, New York, 1972.

43 A. Garcia-Fuentes, S. Wirtz, E. Vos and H. Verhagen, Short review of sulphites as food additives, Eur. J. Nutr. Food Saf., 2015, 5(2), 113-120.

44 C. Booth, Fungal culture media, in Methods in Microbiology, ed. J. R. Norris and D. W. Ribbons, Academic Press, London and New York, 1971, pp. 49-94.

45 C. E. A. Coimbra and J. R. Welch, Enciclopédia dos Alimentos Yanomami (Sanöma): Cogumelos. Edited by R. M. Apiamö, J. Autuori, N. K. Ishikawa, M. S. Martins, N. Menolli Jr., C. Sanuma, L. R. Sanuma, M. Sanuma, O. I. Sanuma, \& K. Tokimoto. 2016. Instituto Socioambiental, São Paulo. 108 pp., Ethnobiol. Lett., 2018, 9(2), 309-311.

46 I. Palacios, M. Lozano, C. Moro, M. D’Arrigo, M. A. Rostagno, J. A. Martínez, A. García-Lafuente, E. Guillamón and A. Villares, Antioxidant properties of phe- nolic compounds occurring in edible mushrooms, Food Chem., 2011, 128(3), 674-678.

47 F. S. Reis, D. Stojković, M. Soković, J. Glamočlija, A. Ćirić, L. Barros and I. C. F. R. Ferreira, Chemical characterization of Agaricus bohusii, antioxidant potential and antifungal preserving properties when incorporated in cream cheese, Food Res. Int., 2012, 48(2), 620-626.

48 D. Stojković, F. S. Reis, J. Glamočlija, A. Ćirić, L. Barros, L. J. L. D. Griensven, I. C. F. R. Ferreira and M. Soković, Cultivated strains of Agaricus bisporus and A. brasiliensis: chemical characterization and evaluation of antioxidant and antimicrobial properties for the final healthy productnatural preservatives in yoghurt, Food Funct., 2014, 5(7), 1602-1612.

49 L. Barros, T. Cruz, P. Baptista, L. M. Estevinho and I. C. F. R. Ferreira, Wild and commercial mushrooms as source of nutrients and nutraceuticals, Food Chem. Toxicol., 2008, 46(8), 2742-2747.

50 S. T. Chang and P. G. Miles, Mushrooms: cultivation, nutritional value, medicinal effect, and environmental impact, CRC, Boca Raton, 2th edn, 2004.

51 TACO - Brazilian Food Composition Table, 11, Nepa Unicamp, São Paulo, Brazil, 2011. https://www.cfn.org.br/ wpcontent/uploads/2017/03/taco_4_edicao_ampliada_e_ revisada.pdf.

52 C. V. Toledo, C. Barroetaveñ, Â. Fernandes, L. Barros and I. C. F. R. Ferreira, Chemical and antioxidant properties of wild edible mushrooms from native Nothofagus spp. forest, Argentina, Molecules, 2016, 21(9), 1-15.

53 C. Arai, N. Arai, A. Mizote, K. Kohno, K. Iwaki, T. Hanaya, S. Arai, S. Ushio and S. Fukuda, Trehalose prevents adipocyte hypertrophy and mitigates insulin resistance, Nutr. Res., 2010, 30(12), 840-848.

54 C. Yoshizane, A. Mizote, M. Yamada, N. Arai, S. Arai, K. Maruta, H. Mitsuzumi, T. Ariyasu, S. Ushio and S. Fukuda, Glycemic, insulinemic and incretin responses after oral trehalose ingestion in healthy subjects, Nutr. J., 2017, 16(1), 1-6.

55 H. Yaribeygi, A. Yaribeygi, T. Sathyapalan and A. Sahebkar, Molecular mechanisms of trehalose in modulating glucose homeostasis in diabetes, Diabetes Metab. Syndr.: Clin. Res. Rev., 2019, 13(3), 2214-2218.

56 J. H. Liu, X. D. Shang, J. Y. Liu and Q. Tan, Changes in trehalose content, enzyme activity and gene expression related to trehalose metabolism in Flammulina velutipes under heat shock, Microbiology, 2016, 162(8), 1274-1285.

57 X. M. Liu, X. L. Wu, W. Gao, J. B. Qu, Q. Chen, C. Y. Huang and J. X. Zhang, Protective roles of trehalose in Pleurotus pulmonarius during heat stress response, J. Integr. Agric., 2019, 18(2), 428-437.

58 I. M. Colla, O. B. Q. Oliveira Filho, J. D. S. Freitas, M. B. D. Bertéli, G. A. Linde, J. S. Valle and N. B. Colauto, Mycelial biomass cultivation of Lentinus crinitus, Biosci. J., 2020, 36(6), 2238-2246, DOI: 10.14393/BJ-v36n6a2020-51183.

59 Y. M. Pacheco, S. López, B. Bermúdez, R. Abia, J. Villar and F. J. G. Muriana, A meal rich in oleic acid beneficially 
modulates postprandial SICAM-1 and SVCAM-1 in normotensive and hypertensive hypertriglyceridemic subjects, J. Nutr. Biochem., 2008, 19(3), 200-205.

60 K. L. Fritsche, Too much linoleic acid promotes inflammation-doesn't it?, Prostaglandins, Leukotrienes Essent. Fatty Acids, 2008, 79(3-5), 173-175.

61 J. Manjunathan and V. Kaviyarasan, Nutrient composition in wild and cultivated edible mushroom, Lentinus tuberregium (Fr.) Tamil Nadu., India, Int. Food Res. J., 2011, 18(2), 809-811.

62 U. N. Das, Essential fatty acids - a review, Curr. Pharm. Biotechnol., 2006, 7, 467-482.

63 A. Leaf, Omega-3 fatty acids and prevention of arrhythmias, Curr. Opin. Lipidol., 2007, 18, 31-34.

64 K. Kyu-Bong, A. N. Yoon, S. K. Hyung, A. W. Hayes and L. Byung-Mu, $\alpha$-Linolenic acid: nutraceutical, pharmacological and toxicological evaluation, Food Chem. Toxicol., 2014, 70, 163-178.

65 N. Blondeau, R. H. Lipsky, M. Bourourou, M. W. Duncan, P. B. Gorelick and A. M. Marini, Alpha-linolenic acid: an omega-3 fatty acid with neuroprotective properties-ready for use in the stroke clinic?, BioMed. Res. Int., 2015, 519830 .

66 I. Ferreira, L. Barros and R. Abreu, Antioxidants in wild mushrooms, Curr. Med. Chem., 2009, 16(12), 1543-1560.

67 Q. Jiang, Natural forms of vitamin E: metabolism, antioxidant, and anti-inflammatory activities and their role in disease prevention and therapy, Free Radical Biol. Med., 2014, 72, 76-90.

68 A. E. S. S. Carvajal, E. A. Koehnlein, A. A. Soares, G. J. Eler, A. T. A. Nakashima, A. Bracht and R. M. Peralta, Bioactives of fruiting bodies and submerged culture mycelia of Agaricus brasiliensis (A. blazei) and their antioxidant properties, LWT - Food Sci. Technol., 2012, 46(2), 493-499.

69 A. M. Kwak, I. K. Lee, S. Y. Lee, B. S. Yun and H. W. Kang, Oxalic acid from Lentinula edodes culture filtrate: antimicrobial activity on phytopathogenic bacteria and qualitative and quantitative analyses, Mycobiology, 2016, 44(4), 338-342.

70 C. Manach, A. Mazur and A. Scalbert, Polyphenols and prevention of cardiovascular diseases, Curr. Opin. Lipidol., 2005, 16(1), 77-84.

71 M. E. Valverde, T. Hernández-Pérez and O. Paredes-López, Edible mushrooms: improving human health and promoting quality life, Int. J. Microbiol., 2015, 2015, 376387, DOI: $10.1155 / 2015 / 376387$.

72 B. Muszyńska, A. Grzywacz-Kisielewska, K. Kała and J. Gdula-Argasińska, Anti-inflammatory properties of edible mushrooms: a review, Food Chem., 2018, 243, 373-381.

73 F. S. Reis, A. Martins, L. Barros and I. C. F. R. Ferreira, Antioxidant properties and phenolic profile of the most widely appreciated cultivated mushrooms: a comparative study between in vivo and in vitro samples, Food Chem. Toxicol., 2012, 50(5), 1201-1207.

74 L. Barros, M. Dueñas, I. C. F. R. Ferreira, P. Baptista and C. Santos-Buelga, Phenolic acids determination by HPLC-DAD-ESI/MS in sixteen different Portuguese wild mushrooms species, Food Chem. Toxicol., 2009, 47(6), 1076-1079.

75 M. Naczk and F. Shahidi, Phenolics in cereals, fruits and vegetables: occurrence, extraction and analysis, J. Pharm. Biomed. Anal., 2006, 41, 1523-1542.

76 H. M. H. Chowdhury, K. Kubra and R. R. Ahmed, Screening of antimicrobial, antioxidant properties and bioactive compounds of some edible mushrooms cultivated in Bangladesh, Ann. Clin. Microbiol. Antimicrob., 2015, 14(1), 1-6.

77 O. Taofiq, S. A. Heleno, R. C. Calhelha, M. J. Alves, L. Barros, M. F. Barreiro, A. M. González-Paramás and I. C. F. R. Ferreira, Development of mushroom-based cosmeceutical formulations with anti-inflammatory, anti-tyrosinase, antioxidant, and antibacterial properties, Molecules, 2016, 21(10), 1-12.

78 F. Bach, A. A. F. Zielisnk, C. V. Helm, G. M. Maciel, A. C. Pedro, A. P. Stafussa, S. Ávila and C. W. I. Haminiuk, Bio compounds of edible mushrooms: in vitro antioxidant and antimicrobial activities, LWT-Food Sci. Technol., 2019, 107, 214-220.

79 J. Cilerdzic, M. Stajic, J. Vukojevic, I. Milovanovic and N. Muzgonja, Antioxidant and antifungal potential of Pleurotus ostreatus and Agrocybe cylindracea basidiocarps and mycelia, Curr. Pharm. Biotechnol., 2015, 16(2), 179-186.

80 S. A. Heleno, I. C. F. R. Ferreira, A. P. Esteves, A. Ćirić, J. Glamočlija, A. Martins, M. Soković and M. J. R. P. Queiroz, Antimicrobial and demelanizing activity of Ganoderma lucidum extract, $p$-hydroxybenzoic and cinnamic acids and their synthetic acetylated glucuronide methyl esters, Food Chem. Toxicol., 2013, 58, 95-100.

81 M. Alves, I. C. F. R. Ferreira, J. Dias, V. Teixeira, A. Martins and M. Pintado, A Review on antimicrobial activity of mushroom (Basidiomycetes) extracts and isolated compounds, Planta Med., 2012, 78(16), 1707-1718.

82 A. M. Younis, F. S. Wu and H. H. El Shikh, Antimicrobial activity of extracts of the oyster culinary medicinal mushroom Pleurotus ostreatus (higher basidiomycetes) and identification of a new antimicrobial compound, Int. J. Med. Mushrooms, 2015, 17(6), 579-590.

83 R. M. R. Dulay, L. A. Miranda, J. S. Malasaga, S. P. Kalaw, R. G. Reyes and C. T. Hou, Antioxidant and antibacterial activities of acetonitrile and hexane extracts of Lentinus tigrinus and Pleurotus djamour, Biocatal. Agric. Biotechnol., 2017, 9, 141-144.

84 R. Manuja, S. Sachdeva, A. Jain and J. A. Chaudhary, Comprehensive review on biological activities of $p$-hydroxy benzoic acid and its derivatives, Int. J. Pharm. Sci. Rev. Res., 2013, 22(2), 109-115.

85 P. Shukla, Food Additives from an organic chemistry perspective, MOJ Bioorg. Org. Chem., 2017, 1(3), 70-79.

86 R. M. Raybaudi-Massilia, J. Mosqueda-Melgar and O. Martín-Belloso, Antimicrobial activity of malic acid against Listeria monocytogenes, Salmonella enteritidis and Escherichia coli, 0157:H7 in apple, pear and melon juices, Food Control, 2009, 20(2), 105-112. 
87 S. Eswaranandam, N. S. Hettiarachchy and M. G. Johnson, Antimicrobial activity of citric, lactic, malic, or tartaric acids and nisin-incorporated soy protein film against Listeria monocytogenes, Escherichia coli, O157:H7, and Salmonella gaminara, J. Food Sci., 2004, 69(3), 79-84.

88 V. K. Chaturvedi, S. Agarwal, K. K. Gupta, P. W. Ramteke and M. P. Singh, Medicinal mushroom: boon for therapeutic applications, 3 Biotech., 2018, 8, 1-20.

89 J. Y. Lee, Y. S. Kim and D. H. Shin, Antimicrobial synergistic effect of linolenic acid and monoglyceride against
Bacillus cereus and Staphylococcus aureus, J. Agric. Food Chem., 2002, 50, 2193-2199.

90 A. Borges, C. Ferreira, M. J. Saavedra and M. Simões, Antibacterial activity and mode of action of ferulic and gallic acids against pathogenic bacteria, Microb. Drug Resist., 2013, 19, 256-265.

91 N. Beales, Adaptation of microorganisms to cold temperatures, weak acid preservatives, low $\mathrm{pH}$, and osmotic stress: a review, Compr. Rev. Food Sci. Food Saf., 2004, 1-20. 